\title{
A missional reflection on the challenges of getting married faced by the poor: A case study from Soshanguve
}

\begin{tabular}{|c|c|}
\hline \multicolumn{2}{|c|}{$\begin{array}{l}\text { Author: } \\
\text { Kasebwe T.L. Kabongo }{ }^{1} \text { (D) }\end{array}$} \\
\hline \multicolumn{2}{|c|}{$\begin{array}{l}\text { Affiliation: } \\
{ }^{1} \text { Department of Religion } \\
\text { Studies, Faculty of Theology } \\
\text { and Religion, University } \\
\text { of Pretoria, Pretoria, } \\
\text { South Africa }\end{array}$} \\
\hline \multicolumn{2}{|c|}{$\begin{array}{l}\text { Research Project Registration: } \\
\text { Project Leader: A. van Niekerk } \\
\text { Project Number: } 02461412\end{array}$} \\
\hline \multicolumn{2}{|c|}{$\begin{array}{l}\text { Description: } \\
\text { This research is part of th } \\
\text { research project, 'Ecodom } \\
\text { The church and sustainab } \\
\text { communities', directed by } \\
\text { Dr Attie van Niekerk, } \\
\text { Department of Science of } \\
\text { Religion and Missiology, } \\
\text { Faculty of Theology and } \\
\text { Religion, University of } \\
\text { Pretoria. }\end{array}$} \\
\hline \multicolumn{2}{|c|}{$\begin{array}{l}\text { Corresponding author: } \\
\text { Kasebwe Kabongo, } \\
\text { kablut@yahoo.fr }\end{array}$} \\
\hline \multicolumn{2}{|c|}{$\begin{array}{l}\text { Dates: } \\
\text { Received: } 09 \text { Mar. } 2020 \\
\text { Accepted: } 12 \text { May } 2020 \\
\text { Published: } 29 \text { June } 2020\end{array}$} \\
\hline \multicolumn{2}{|c|}{$\begin{array}{l}\text { How to cite this article: } \\
\text { Kabongo, K.T.L., 2020, 'A } \\
\text { missional reflection on the } \\
\text { challenges of getting marrie } \\
\text { faced by the poor: A case } \\
\text { study from Soshanguve', } \\
\text { HTS Teologiese Studies/ } \\
\text { Theological Studies } 76(3) \text {, } \\
\text { a5980. https://doi.org/ } \\
\text { 10.4102/hts.v76i3.5980 }\end{array}$} \\
\hline \multicolumn{2}{|c|}{$\begin{array}{l}\text { Copyright: } \\
\text { (C) 2020. The Authors. } \\
\text { Licensee: AOSIS. This work } \\
\text { is licensed under the } \\
\text { Creative Commons } \\
\text { Attribution License. }\end{array}$} \\
\hline \multirow[b]{2}{*}{$\begin{array}{l}\text { Read online: } \\
\text { 口ifin: }\end{array}$} & \\
\hline & $\begin{array}{l}\text { Scan this QR } \\
\text { code with your } \\
\text { smart phone or } \\
\text { mobile device } \\
\text { to read online. }\end{array}$ \\
\hline
\end{tabular}

This is a case study that is written from the perspective of a black African who lives in a community of poverty. He has observed a growing number of adults who desire to get married, but only cohabit. He formed a focus group with five cohabiting couples who desired to get married. Through this focus group, they discussed impediments of getting married as well as alternatives for converting challenges to resources that would make marriage a reality. A mission practitioner who values being a tangible sign of hope through involvement in social matters catalysed the happenings of this case study through a group he put together. The results of the focus group reveal stories of both success and failure.

Keywords: bride price; cohabit; financial management; impediments; marriage and solutionseeking.

\section{Introduction}

Marriage is an important institution in our society as well as in the church. The value of this institution seems to be under scrutiny in view of an increasing number of adults who cohabit instead of getting married. Semenya (2016:1) stresses that there is a 'rising trend in cohabitation reflected in South African statistics'. The 2001 census estimated that nearly 2.4 million South Africans were cohabiting as partners.

InnerCHANGE, a Christian missional order, decided to interact with the issue of marriage as experienced in the South African township of Soshanguve. The aim of this effort was to be missional in tangibly being involved in solution-seeking. The concept of missional is understood as 'the radical application of Christ's kingship over the whole of life and the goal of addressing people in their total environment' (Van Niekerk 2015:3). Hirsh and Frost's (2003:30) understanding of missional is the church 'engagement with culture and the world in the same mode as the messiah himself'. InnerCHANGE values engaging the culture around it in order to generate stories of hope from the inside out.

The author is part of InnerCHANGE. He has been involved with young adults and middle-aged men as he played soccer with them weekly. After several months of getting familiar, he was invited to these friends' homes. The vast majority of these neighbours cohabited with their partners. They first introduced these partners as wives. It was only a few months later when their partners got familiar with the author after several casual visits that they disclosed their true marital status. However, they also expressed their desire and longing to get married to their partners and my friends. Many of them expressed their desire in a complaining way, such as 'Please convince your friend to make a plan to marry me'. After hearing this complaint from their partners, many of these friends were at first embarrassed and many times later they also expressed their desire to get married and talked about the impediments that stood in the way of making their longing to come true.

The author started grappling with this issue of marriage with the aim of helping people with the desire to get married by proactively participating in lifting the impediments they face. His involvement was also motivated by the black African value in marriage he grew up with and also observed in Soshanguve. In fact, after the author was past his teenage years, the elders of his family encouraged him to get married. Part of the reasons for this encouragement was because in the African traditional societies a bachelor is 'not considered as an adult' (Mbiti 2015:134). These societies are hierarchical and patriarchal. They only considered the voices of adults and men. 
The experience of knowing many neighbours, such as the soccer teammates, who value and desire to get married and the reality of seeing few marriages in local churches and in the community motivated the formation of a focus group of five cohabiting partners so that 'in-depth investigations' could be conducted after hearing stories straight from the horse's mouth (Polit \& Beck 2008:235). This article is, therefore, a case study of a qualitative research that aims to demonstrate how the body of Christ could get involved in real issues affecting ordinary people. This question guides it: how can the church interact with an issue such as marriage in a way that can empower people to become part of the answer of the impediments they face? Marriage has the potential to have a positive effect on the spouses' commitment to one another and their involvement with their children. There seem to be many impediments that prevent many willing cohabiting couples from getting married to do so. The discussions of the focus group will shed light on these impediments. The focus group was formed by taking into consideration ethical guidelines that are required in academic research.

\section{Ethical consideration}

All the focus group participants were invited by the author to be part of this conversation and discussions. All of them had to fill in a consent letter in order to participate in this research. The consent letter described the nature and aim of the study. It also included the participants' rights to privacy (hence this research does not use names), voluntary participation and confidentiality. Krueger and Casey (2002) advised that a 'focus group be between 6 and 12 people' for in-depth and quality interactions that would be credible. The author journeyed with 10 adults. Together, they were part of the discussions that took place.

\section{The focus group discussions}

As alluded to earlier, the five men involved in this focus group played soccer with the author every Sunday morning. The churchgoers went to their congregations after the match. The majority of the team comprised de-churched people. Many of those who cohabited freely shared that with the author, except the five men who participated in this focus group because they knew he was a pastor. Therefore, the author only discovered that the five men were not married after he visited their houses on several occasions and their partners told him. Of the five couples, three of them had partners who went to different local churches (the mother going to church with children and the father going alone). They were known as married at their respective churches. One couple were members of one church. And the last couple had a Christian man who belonged to a local church and the woman was at not yet a believer in Christ. Semenya (2016:3) points out that the phenomenon of cohabitation is a reality in South African churches, although Christianity sees cohabitation as sinful.

The real issue that led to the forming of our focus group was the desire of the five couples to get married and to overcome the impediments that prevent them from doing so. The author invited his wife to join this focus group to enrich the quality of conversations that were going to take place. The focus group met once a quarter for 3 years. The author and his wife met together with these five couples. The latter wished to get married, but felt stuck. The goal of these gatherings was to help individuals and couples discover how they were part of the problem as well as how they could be part of the solution in making their desire to get married, a reality.

In the initial conversations about why the five couples were not married, in spite of wanting to, all the individuals talked about the main reason being poverty. The reality of poverty is indeed noticeable in the township of Soshanguve. South Africa has a high unemployment rate and its economy is struggling which means that more jobs are reduced than created. In the latest statistics on employment, the official unemployment rate jumped to $29 \%$ in the second quarter of 2019 (Fin24.com 2019). The youth are usually the age group that needs to get married, yet the 'unemployment rate for the youth is 56.4\%' (Fin24.com 2019). Out of the five couples, only three were employed and the employed partners were the men.

The history of Africa includes a period of colonialism that has some impact on the current state of poverty. Mbuli (2008:2) stresses that 'South Africa is disfigured by widespread poverty, with almost half of the South African population being categorized as poor in terms of the national poverty line'. The poverty of the majority of South Africans is also connected to the kind of education they receive. History tells us that in 1955 Bantu education was imposed on black people. Nkabinde (1997:5) stresses that the Bantu education aimed 'to provide a separate and unequal education to different races of South Africa'. Until today, Bantu education is still a permanent resident in South Africa because the majority of educators are Bantu education graduates who are imparting a below-par quality of education, even with the best intentions (Kabongo 2019:32).

Terreblanche (2003:13-14) points out that the low levels of education of many black Africans have made them ineligible for employment in the tertiary sector'. This explains the current 'huge inequalities in the distribution of power, property and income' in South Africa (Terreblanche 2014:4). Poverty is also connected to the location of people's residence. The majority of jobs are still centralised in the city centre and suburban areas. Many people living in townships such as Soshanguve not only spend several hours to go to work; they also spend a large percentage of their salaries on transport. A World Bank report (2019:xiv) rightly points out that 'location has implications on the travel costs' and the disposable income of people.

Getting married involves many expenses. For people who are unemployed, such expenses will be impossible to cover. Even for low-income earners like the majority of our neighbours, to cover those expenses is challenging. In the 
back African culture, one of the things that is most important in order for a marriage to take place is the bride price (commonly known as lobola in South Africa). Shumba and Landman (2019:1) say that the payment of the bride price by a man 'is an exhibition of love, which exhibits great commitment of the bride and groom to marriage'. Mbiti (2015:113) states that the bride price 'is a gift given to the lady's family to remind them that she is not dead but given away under mutual agreement between the two families'. The Asante from Ghana views it as 'a token of gratitude for care over the bride and for allowing her to become his wife' (Oduyoye 1998:349). However, the five men in the focus group mentioned that nowadays the bride price is very expensive and commercialised. It could be said that the bride price is being commercialised in many African communities. Theron (2002:74) stresses that the commercialisation of the bride wealth 'is one of the biggest problems. Extravagant amounts are asked by the' lady's family. Many young men cannot afford such extravagant amounts. Shumba and Landman (2019:12) stress that in Zimbabwe, 'the commercialized bride price has become a challenge ... Charging exorbitant lobola has become an obstacle to canonical marriage because of the high price demanded by the bride's family'. Semenya (2016:2) believes that exorbitant price is 'a significant contributing factor leading' many couples to just cohabit and not get married. The current commercialisation of marriage placed against the disposable income of an ordinary person living in a town or a person living in poverty explains why getting married is increasingly seen as a luxury. The Rwandan Jean-Baptiste Gahamanyi (1981:104) remarks that 'two-thirds of young people of marriageable age enter into concubinage and free unions' because they cannot afford to pay the bride price. The Kenyan Obetia (2015:114-115) talks about heavy financial expenses when paying the bride price that prevent many young people from getting married. And those who do so engage in a luxurious practice.

At the beginning of our focus group meetings we prayed. One of the things we regularly prayed about was for people to get jobs. Both men and women wanted to get jobs. They saw employment as a step forward in their desire to get married. After 6 months, all the men in the group were employed and so were three women. I have learned that a man involved in a romantic relationship such as marriage or cohabitation stood a good chance to be employed. Unfortunately, 'the opposite is true for women in that they are least likely to be employed when living with their partner' (Janse Van Rensburg, Claassen \& Fourie 2019:7). The issue of employment brought up some serious challenges about financial management during our discussions.

Individuals started accusing their partners of misusing money which was an impediment to their goal to get married and improve their family's standard of living. Alsemgeest and Grobbelaar (2015:843) point out that the conduct of marital partners with regard to the way in which they spend money can influence the success of their relationship'. In the first few sessions of the focus group, the author and his wife had to deal with a lot of resentment from the women. The latter complained that their partners did not prioritise the desire to get married in their current financial situation. Even those men who were unemployed had worked before. In this group, we were dealing with couples who had been cohabiting for between 5 and 10 years. The men, on the contrary, complained about their partners' money spending habits that negatively affected their household and the possibility of saving money towards the bride price and expenses for the wedding function. Alsemgeest and Grobbelaar (2015:855) point out that 'finances play a major role in the life of every individual' and a couple. According to them 'South Africa ... considers communication about finances inappropriate' which leads to conflicts in a relationship and a split. When it comes to household finances, Alsemgeest and Grobbelaar (2015:855) point out men tend to have a lower opinion regarding their partners' 'ability to distinguish between luxuries and essentials'. This sentiment came out in the group with men blaming their partners for the mismanagement of finances.

This mutual blame game brought to mind Tolstoy's (2019:1) saying: 'everyone thinks of changing the world, but no one thinks of changing himself [sic]'. A process of inner change was needed for everyone to be the change they wished to see in the world around them (Maathai 2009:3). It was important to help couples realise that they both were part of the problem and solution to getting married. They, therefore, had to be proactive participants in making their wish come true.

Helping the five couples to become the answer to their prayer to get married was the cornerstone of all our conversations. Mark 1:16-20 inspired group conversations. In this passage, Jesus uses the skill of fishing, which the people he invited had, as a metaphor of the role these invitees now had to play on their journey together. We hoped couples would form shalom partnerships in which their family problems and their resolve will be a concern and responsibility of both of them (Linthicum 2003:38).

Our initial conversations also had to engage the issue of showing off prevalent in the culture. Many people believe in being seen as successful - as having money - by acquiring expensive things. Such a worldview makes many of our neighbours to want to live beyond their means. Even some low-income earners who cohabit tend to give up on getting married because it would not be fun and meaningful if not expensive. This worldview is not unique to Soshanguve. In reflecting on his Ugandan context, Ssentongo (2018:1) stresses that many people living in poverty like to pretend and show off that they have climbed the ladder of social classes. Engaging the issue of showing off meant talking about the bottom line of people's heart's desire. This led to talking about happiness.

As a focus group, we came to an agreement that being happy has to do with doing the right thing both culturally and faithwise, live in a functional relationship and raise children in a 
functional home. Happiness had to do with having the best quality of life possible that will improve the flourishing of their lives as individuals, a couple and a family. Niemandt (2016:2) sees flourishing life as 'essential to individual thriving and the global common good'.

During our conversations, it turned out that poverty and finances were not the only reasons people were cohabiting and not getting married. Three men mentioned that they needed to make sure that their girlfriends could get pregnant with their child before they could think about getting married. Two of these three men even say they needed to have a boy child before they could think about getting married. Oladeji and OlaOlorun (2018:1) say that in Africa 'a high premium is placed on child-bearing. Women with fertility problems may be despised, neglected or abused by their husbands and extended family'. Infertility leads to many mental issues in women. In our African patriarchal society, 'infertility is culturally considered as a problem of women' (Oladeji \& OlaOlorun 2018:2). In Soshanguve, 'childbearing in a marriage, with special emphasis on the birth of boys' is highly valued (Janse Van Rensburg et al. 2019:7). The author has also met many women in dating or cohabiting relationships with men working hard to get pregnant and preferring to give birth to a boy as a way to motivate their partner to marry them. So, this cultural prejudice has been propagated by many women. And it is still perpetuated by many men.

The group discussions also brought to the fore a cultural prejudice that seems to be accepted by the church about the submission of women. Four men said that they can only get married to submissive women. Some even pointed out to their difference in opinion about financial management and the prioritisation of household things, as a case of lack of submission of their cohabituating partners. These men saw their perspective as wisdom and any different perspective as defiance to wisdom. The submission of women to men is a prevalent cultural belief in the township of Soshanguve. This cultural belief is prejudiced against women. Chisale (2018:1) connects this cultural belief to 'the domestic violence that is prevalent in black African communities'.

All these insightful conversations needed to be engaged in a way that would challenge and empower these five couples to be the main solution to their desire to get married. We needed to interact with the different problems and challenges raised, and use them as resources for solution-seeking.

\section{Interaction with problems for solution-seeking}

In this section, the author reflects on how he and his wife led the group to (de) constructively tackle the impediments they faced. It was critical to challenge the group to not be normal, but kingdom like. What is normal in our community is a very high bride price and expensive wedding celebrations, although the majority of our neighbours are poor. Therefore, poverty and very expensive engagements seem paradoxical. Learning to be kingdom like meant making decisions according to someone's financial means, learning to focus on the meaning of a wedding celebration rather than the details of the celebration. This argument seemed to be an easy sell for the men, not so much for the ladies of our group. For the latter, it was important to fit into the culture and be seen as successful. They also strongly believed that the one way towards getting married was to make more money.

The fact that all the men in the group were employed and some ladies too was a significant boost in our conversations. Getting married involves expenses. Therefore, financial preparation was critical. We talked to the couples about the need for them to discuss their monthly incomes and expenses so that they can start saving for expenses towards their marriage. At this stage, two gender-orientated views on money arise and are contradictory. It took us more than a year to see some positive results in three couples; two others remained stuck at this level. All the men in the group believed that you should not tell your partner how much you earn. If she knows, you will not be able to spend money on other things such as taking care of the financial needs of your parents and siblings.

The Congolese culture that the author grew up in also follows this belief system. The women, on the contrary, held the view that money is there to be spent. If the household runs out of money in the middle of the month, which happened almost every month, it was the man's responsibility to make a plan for the month. In their study conducted in a poor township of Kwazulu-Natal, Bhana and Pattman (2011:1) found out that many women's love for a man had to do with how well a man could provide financially. The financial reality we faced was that these five couples lived on credit every month and did not save any money. Having debts seems to be a normal thing in the community. Many of our neighbours believe that an adult cannot live without debt. The couples were challenged to relinquish individual views on money, put out in the open their incomes and expenses, and decide which expenses to cut out so that they could live within their means. We also taught them about budgeting so as to save $5 \%$ of their income towards their wedding and 5\% for family emergencies.

Because the bride price seemed to be a key impediment, we encouraged couples to save towards it together. Culturally, it seems to be the man's responsibility. We thought that a couple's ability to save money together will increase the prospect of getting married. We suggested that their yearlong savings would help in paying the bride price $(50 \%)$ and the expenses towards the wedding celebrations (50\%). Once a couple was disciplined enough to save money for 6 months, we encouraged the lady to start talking to her parents about getting married and how much bride price her fiancé could afford. Traditionally, the women's family decides on the bride price to ask from the man's family (nowadays, the groom-to-be has to pay from his own pocket). It was critical 
to make parents to come up with a realistic price tag. The request to talk to parents was very hard for the women because the bride price is a taboo subject that only parents talk about and decide upon. Nonetheless, all of them were willing to take up this challenge after many discussions.

It was critical to involve their local churches because at least one partner of a couple, was a churchgoer. We wanted local churches to be involved as a support system for their members wanting to get married. We also wanted the pastors from these local churches to get their members married. Many pastors in the community start getting involved with a to-be-married couple only after the bride price is paid and all the traditional ceremonies are already finalised. We wanted to cautiously challenge this practice by inviting ministers to help in dealing with the realities of getting married.

With regard to the world views about childbearing and women being submissive before getting married, some (de) constructive conversations were considered. We used the Bible as the main reference of discussions. We used Mark 10:7-9 that talks about a man and a woman leaving their families to become one, to stress that a man and a woman are equal partners in a relationship. Some of the implications of this partnership are mutual love, mutual submission and the sharing of taboo issues such as finances. We also stressed that children are the fruits of a relationship such as marriage and should not be a pre-condition for marrying a woman. One of the men in the group stressed the fact that culture obliges men to pay the bride price, put men in a position of power and authority over women. He stressed that the culture should do away with the bride price. Some feminist scholars agree with this man. Hague, Thiara and Turner (2011:550) stress the fact that 'in situations where domestic violence is common, bride-price introduces additional ways in which men can justify the abuse of women'. According to them, the bride price is commercialised and commoditised in many African communities, and this situation has abusively increased the 'male power over women' (Hague et al. 2011:550). A discussion about the relevance of a bride price or not could be important to engage, here. However, it is not the focus of this research.

As stated earlier, the author is part of InnerCHANGE, a missional team that values engagement in social matters. This missional team made the commitment to meet half-way the couples who made an effort to save money towards their marriage. It did some fundraising in printing out T-shirts and sold them to extended family members and friends of a couple. The profits from the fundraiser went to the couple to be married. InnerCHANGE also offered to conduct the wedding function (party) of a couple according to the budget they had.

The author's wife runs a catering company. She sometimes gives back to her community by helping to conduct functions in low cost. The five couples of this focus group would also benefit from her generosity if they were able to save money towards their goal of getting married. This effort was made because we believe in solidarity. Churu (2015:146-147) rightly pointed this out: 'the true African community lives in solidarity in order to safeguard its values and its survival'. InnerCHANGE also wanted to be in solidarity with its neighbours in this way. What did these discussions amount to? The following section shares the outcome of these efforts.

\section{Focus group outcome: Results of interaction with solution statements}

After 3 years of journeying together as a focus group, two couples were able to get married. The two couples learned the discipline of saving money. The ladies talked to their parents about how much bride price their fiancé could afford. There was a lot of tension, disagreements and tears at this stage because families are used to the normal, which was asking for the price they wanted. In the end, parents wanted their children to be happy and received with joy what was affordable.

One couple started saving money only after 2 years of group meetings. It seemed to be hopeful about its plan and desire. Two couples still struggled to save money and could not move forward in their goal.

The author hoped to see these couples become a testimony to their community and the church that getting married is possible if the willpower to make a desire a reality is present. It takes discipline, dedication and persuasion when talking to families about bride price and the details of the wedding celebration. The author hopes that such testimony would encourage others to get married. This focus on helping ordinary people get married was also motivated by his observation of many children and teenagers InnerCHANGE works with. He has observed that the majority of these children and teenagers who come from families where both parents are involved in their lives have a good discipline record and interact well with authority figures. Many of these parents are also involved with InnerCHANGE as a community-based organisation one way or another.

Marriage is a public commitment for someone. Communities with poverty such as Soshanguve need committed partners who can build functional families. Van Niekerk (2015:2-3) says that family in Africa is one of the only few institutions 'that has always...successfully taken care of all the elderly, the orphans, the handicapped, the unemployed and the underemployed'. Marriage can strengthen the foundation of a family so that it can better take care of its members. The church could make a meaningful contribution to society if it creatively gets involved in issues such as marriage that has the potential not only to strengthen a family, but also a whole community (Theron 2002:4). Marriage, especially a functional one, can also be a better platform to raise the vulnerable population such as children. Selvam (2015:123-124) says that 'the family is the centrepiece of all human societies'. It is because of this that evolution happens through the care of children and young people. Good care of children in families has good implications on the health of a community 
and a nation. Selvam analyses the attachment theories in connection to relationship building in society. Selvam (2015:128-129) stresses the fact that individuals with 'a secure attachment in childhood' tend to be faithful in relationships. Faithfulness builds a community. A functional marriage is, therefore, a potentially good platform to raise children who will have a secure attachment and will build healthy relationships in all spheres of the society which could lead to the improvement of the quality of life for all in a given society.

\section{Reflections}

The outcome of these efforts is one of the ways InnerCHANGE expresses its missional mandate to be involved in social matters. In such involvement, it hopes 'to inspire people to be agents and embodiments of the life of God's new creation in Jesus Christ' in being agents of their own desires (Kirk 1997:7). It believes in 'a theology of participation' which involves the church and a community to work together in finding solutions that are mutually beneficial (Moltmann 1981:139). It sees itself as 'an incarnational movement sent to engage its context' in tangible and meaningful ways (Niemandt 2012:4). This is why, through its staff, it was engaged in a real issue such as marriage. It agrees with Vorster (2016:7-8) that marriage has the potential to establish 'permanent relations of mutual trust, stewardship and love on an equal basis'. It also has the potential to build a functional and altruist relationship that can build a family and the society in general.

Churu (2015:145) says that there 'is an opportunity for the church to re-appropriate such a practice since it is valued, yet frequently misinterpreted and misused'. Nowadays, poverty seems to be a threat to the institution of marriage. The high value of bride price and cultural worldview connected to the fertility of women before being married and submission also seem to be a threat to the institution. InnerCHANGE believes that as a church, we are called 'to live in solidarity with and responsibility for the world' (Barth 2004). Such a posture could lead to a partnership between the church and communities which could lift many social impediments such as the challenges of the getting married, and create shalom communities. Robert Linthicum (2003:38) defines a shalom community as 'an environment where socio-economic justice is available to all and community's problems and their resolve is a concern for all'. The author would also add that socio-economic success will also be celebrated by everyone. InnerCHANGE along with the township of Soshanguve celebrated the marriage of two couples and would like to see many more couples getting married in affordable ways.

\section{Conclusion}

This case study captured a 3-year journey of six couples: the author and his wife as well as five co-habiting couples. They formed a focus group which aimed to discuss and figure out the possibilities of these cohabiting couples to get married. These couples desired to get married.
During their discussions, several issues came up which proved to be impediments for these couples to get married: poverty, unemployment, the commercialisation of bride price, financial management and cultural worldviews.

The latter were a turning point in helping the five couples that they were part of the problem in the fact that they struggle to make their desire to get married come true. Some of the couples were also part of problem through their financial management.

The five couples also agreed to become part of the solution to the fulfilment of their desire. They committed to save money towards getting married. They learned to focus on what they could afford. Some of the ladies even reached out to their parents to negotiate an affordable bride price. In the end, two couples that took the instructions from the facilitators got married and there was a good prospect of another marriage in the near future. Two couples remained stuck on not managing their finances well and could not get married. An important lesson drawn from this focus group was that in social challenges, the victims can both be part of the solution and part of the problem.

\section{Acknowledgements}

The author is thankful to all the focus group members for their participation in this research.

\section{Competing interests}

The author has declared that no competing interests exist.

\section{Author's contributions}

The author declares that he is the sole author of this research article.

\section{Funding information}

This research received no specific grant from any funding agency in the public, commercial or not-for-profit sectors.

\section{Data availability statement}

Data sharing is not applicable to this article as no new data were created or analysed during this study.

\section{Disclaimer}

The views and opinions expressed in this article are those of the author and do not necessarily reflect the official policy or position of any affiliated agency of the author.

\section{References}

Alsemgeest, L. \& Grobbelaar, C., 2015, 'Spouses' views of gender roles: Financial management in marriage', Journal of Economic and Financial Sciences 8(3), 843-860. https://doi.org/10.4102/jef.v8i3.125

Barth, K., 2004, Community, state, and church: Three essays by Karl Barth with a new introduction by David Haddorff, Wipf and Stock Publishers Eugene, Oregon. 
Bhana, D. \& Pattman, R., 2011, 'Girls want money, boys want virgins: The materiality of love amongst South African township youth in the context of HIV and AIDS' Culture, Health \& Sexuality 13(8), 961-972. https://doi.org/10.1080/13691058.2 Culture, Heath

Chisale, S.S., 2018, 'Domestic abuse in marriage and self-silencing: Pastoral care in a context of self-silencing', HTS Teologiese Studies/Theological Studies 74(2), 4784. https://doi.org/10.4102/hts.v74i2.4784

Churu, B., 2015, 'Elements of the African marriage and family that can be usefully adopted for the pastoral care for Christian families', in G. Caramazza \& B. Chur (eds.), African family today, pp. 140-155, Paulines Publications Africa, Nairob.

Fin24.com, 2019, viewed 30 July 2019, from https://www.fin24.com/Economy/justin-sa-unemployment-rate-jumps-to-29-the-worst-since-2008-20190730.

Fin24, 2019. SA unemployment rate jumps to $29 \%$. The worst since 2008, viewed 30 July 2019, from www.fin24.com.

Frost, M. \& Hirsch, A., 2003, The shaping of things to come. Innovation for the 21st century church, Hendrickson Publishers, Peabody.

Gahamanyi, J.B., 1981, 'Two problems: Bridewealth and polygamy', AFER 23, 104-106. https://doi.org/10.2753/PET1061-19912307104

Hague, G., Thiara, R.K. \& Turner, A., 2011, 'November. Bride-price and its links to domestic violence and poverty in Uganda: A participatory action research study', in Women's studies international forum, vol. 34, no. 6, pp. 550-561, Pergamon Oxford.

Janse Van Rensburg, C.C., Claassen, C. \& Fourie, A., 2019, 'The relationship between marital status and employment in South Africa', Journal of Economic and Financial marital status and employment in South Africa', Journal of Econ
Sciences 12(1), a244. https://doi.org/10.4102/jef.v12i1.244

Kabongo, K.T.L., 2019, 'A missional approach to school dropout in a poor urban area of South Africa', Unpublished doctoral thesis, University of Pretoria, Pretoria.

Kirk, A., 1997, The mission of theology and theology as mission, Gracewing Publishing, Valley Forge, PA.

Krueger, R.A. \& Casey, M.A., 2002, 'Designing and conducting focus group interviews', viewed 20 April 2020, from pdfs.semanticscholar.org.

Linthicum, R.C., 2003, Transforming power: Biblical strategies for making a difference in your community, Intervarsity Press, Downers Grove, IL.

Maathai, W., 2009, The challenge for Africa. A new vision, William Heinemann, London.

Mbiti, J.S., 2015, Introduction to African religion, Waveland Press, Long Grove.

Mbuli, B.N., 2008, 'Poverty reduction strategies in South Africa', Doctoral dissertation, University of South Africa, Pretoria.

Moltmann, J., 1981, The trinity and the Kingdom, Fortress, Philadelphia, PA.

Niemandt, C.J.P., 2012, 'Trends in missional ecclesiology', HTS Teologiese Studies/ Theological Studies 68(1), Art. \#1198, 1-9. https://doi.org/10.4102/hts.v68i1.1198

Niemandt, C.J.P., 2016, 'Rediscovering joy in costly and radical discipleship in mission', HTS Teologiese Studies/Theological Studies 72(4), a3831. https://doi.org/10.4102/ hts.v72i 4.3831
Nkabinde, Z.P., 1997, An analysis of educational challenges in the new South Africa, University Press of America, Lanham, MD.

Obetia, R.R., 2015, 'Christian marriage and African culture', in G. Caramazza \& B. Churu (eds.), African family today, pp. 114-119, Paulines Publications Africa, Nairobi.

Oduyoye, M.A., 1998, 'A critique of Mbiti's view on love and marriage in Africa', in J.K. Olupona \& S.S. Nyang (eds.), Religions plurality in Africa. Essays in honour of John S. Mbiti, pp. 341-360, De Gruyter, Berlin.

Oladeji, S.A. \& OlaOlorun, A.D., 2018, 'Depression among infertile women in Ogbomosoland', South African Family Practice 60(2), 41-45. https://doi.org/10. 1080/20786190.2017.1370840

Polit, D.F. \& Beck, C.T., 2008, Nursing research. Generating and assessing evidence for nursing practice, 8th edn., Lippincott Williams \& Wilkins, Hong Kong.

Selvam, S.G., 2015, 'Pastoral care of the family in the light of sound psychology', in G. Caramazza \& B. Churu (eds.), African family today, pp. 121-129, Paulines Publications Africa, Nairobi.

Semenya, D.K., 2016, 'A pastoral evaluation on the issue of "vat en sit" with special reference to the Black Reformed Churches of South Africa', HTS Teologiese Studies/Theological Studies 72(1), a3050. https://doi.org/10.4102/hts.v72i1.3050

Shumba, S. \& Landman, C., 2019, 'Towards the inculturation of marriage rituals in the National Baptist Convention of Zimbabwe', HTS Teologiese Studies/Theological Studies 75(1), a5432. https://doi.org/10.4102/hts.v75i1.5432

Ssentongo, J.S., 2018, 'Our show-off culture impedes development', viewed 12 August 2019, https://observer.ug/viewpoint/56919-our-show-off-cultureimpedes-development.

Terreblanche, S., 2003, A history of inequality in South Africa, 1652-2002, University of Natal Press \& KMM Review Publishing, Pietermaritzburg.

Terreblanche, S., 2014, Western empires, Christianity, and the inequalities between the West and the rest 1500-2010, Penguin Books, Johannesburg.

Theron, P.F., 2002, African traditional cultures and the church, IMER: University of Pretoria, Pretoria.

Tolstoy, L., 2019a, viewed 15 August 2019, from www.goodreads.com.

Tolstoy, L., 2019b, Death of Ivan Ilych. BLURB, San Francisco, CA.

Van Niekerk, A.S., 2015, 'Guidelines for visits to households. Mission in practice module', Unpublished paper, University of Pretoria.

Vorster, J.M., 2016, 'Marriage and family in view of the doctrine of the covenant', HTS Teologiese Studies/Theological Studies 72(3), a3218. https://doi.org/10.4102/hts. v72i3.3218

World Bank Document, 2019, 'Overcoming poverty and inequality in South Africa. An assessment of drivers, constraints and opportunities', viewed 09 August 2019, from http://documents.worldbank.org/curated/en/530481521735906534/pdf/ 124521-REV-OUO-South-Africa-Poverty-and-Inequality-Assessment-Report-2018FINAL-WEB.pdf. 